\title{
Children and Youth for hire: a case study of the Sungu Sungu in rural Kenya
}

\author{
Caroline Marygorety Akinyi Otieno
}

\begin{abstract}
The paper examines social movements and networks the youth in Kenya have formed in the past decades.

World over, social movements are a type of group action with focus on specific political or social issues. In other words, they carry out, resist or undo a social change. Social network on the other hand is a social structure made up of a set of social actors with dyadic ties providing a set of methods for analyzing the structure of the whole social entities, as well as theories explaining the patterns observed in these structures. The youth in Kenya namely Bagdaad, Mungiki, Sungu sungu, Kamjesh, Chinkororo, Musumbiji, Pwani si Kenya and many others are in a unique kind of social movement because of having similar background of social economic status which has driven them to the situations they are in today thus making them vulnerable in the society. The objective of the study is to demonstrate the social dynamics of post Independent African economies that Government are turning a blind eye on.

The study will be guided by the theory of Anomie which explains that environment shapes the individual in society and mass society theory which argues that social movements provide a sense of empowerment and belonging that the movement members would otherwise not have since such members may have been socially detached.

The methodology use observation, key informants interview with group members to find out the factors that have compelled them into such life styles.

It is hoped that the findings of this study could help to inform policy, which will improve the lives of these people so that they can leave such social networks and movements where they make fellow citizens live in fear.
\end{abstract}

Key words: youth, social movements, social networks, vulnerability

\section{Overview}

The paper examines social movements and the networks formed by Kenyan Youth in the past decade. This paper was prepared from secondary data and brief primary data of two case studies after researching publicly accessible information currently available within time constraints. Document analysis and newspaper review was very key to the information search, besides desk review of current surveillance reports by the human rights watch organizations.

\subsection{Background information}

The Sungu Sungu group is a youth social network with several characteristics. The group is characterized by a variety of sources as an organized criminal group (ISS 2007); a community vigilante group (Human Rights Watch, 2013; Masese and Mwenzwa, 2012); a clan-based militia (RECSA 2011); a community policing group (U4 23 Feb. 2012; Heald, 2007); and as a "grass roots law and order organization" (Masese and Mwenzwa, 2012).

The UN humanitarian news service, the Integrated Regional Information Networks (IRIN), indicates that Sungu Sungu operates widely in Nyanza Province (UN 22 Feb. 2008). Sources further report that within Nyanza Province, the group is operational in the Kisii County and many parts of Migori County. In Migori County the Sungu Sungu is active in the Kuria district resided (Heald 2009; Masese and Mwenzwa 2012).

\subsection{Historical development}

The first Kenyan Sungu Sungu group began in Kuria in 1998 (Heald 2009) while they began in Kisii much earlier in the late 1990s (Masese and Mwenzwa 28 Jan. 2012). Suzette Heald, reports that the Sungu Sungu originally developed due to a lack of police protection from cattle 'thieving' (Heald 2007). He stated that "the Sungu Sungu are used and arise when the government fails or cannot act. They administer justice themselves and, when asked by the government, deal with crimes the government "cannot or will not deal with". In an academic paper on the structure and activities of the Kisii Sungu Sungu, published in Elixir Social Science, Masese and Mwenzwa note that the first Sungu Sungu groups developed due to an "increasing crime rate due to high unemployment and poverty levels, [and] ineffective government security and judicial systems" (Masese and Mwenzwa, 2012). In a book chapter written on the origins, activities and structure of the Kuria 
Sungu Sungu in Tanzania and Kenya, Suzette Heald notes that the Sungu Sungu directly undercut the very rationale of the official agents of the law (Heald 2009). Heald stated that there are many groups [and people] going under the banner of Sungu Sungu and they rise and fall over time. Heald indicated that Sungu Sungu is a particular type of vigilante group and that there are many groups and peoples that form Sungu Sungu groups. Some groups use the name of Sungu Sungu and some do not. It very much varies and it is thus hard to determine specifically where they are active. Further, she indicates that statistics don't exist - knowledge of them comes almost exclusively from long term research.

The online news source Open Democracy (2009), noted that in the Kisii district, the Sungu Sungu started by helping fight crime as a community policing group, but has now become a militia for hire. Heald, referring to Kuria Sungu Sungu, states that external observers and Human Rights Commissions regard the groups as 'vigilantes'. However, at the community level, they receive little but praise when they are deemed to be working well.

\subsection{Government involvement}

Kenyan newspapers report that in 2013, the Kenyan government released a list of 46 criminal gangs that included the Sungu Sungu (The People 31 Aug. 2013). In 2010, the Kenyan government had created the Prevention of Organized Crimes Act, outlawing 33 organized criminal gangs, including the Sungu Sungu (The Star 21 Oct. 2010; The Standard 20 Oct. 2010). In 2008, the Sungu Sungu had been declared a prohibited criminal organization by the Kenyan government (UN 2008). However, Masese indicates that the government particularly relies on the Sungu Sungu since the new constitution was passed in 2010. The new constitution requires criminals to be taken into court within a short amount of time and evidence is required to bring them to court. Often the police and government cannot get evidence in the amount of time required by the constitution and rely on community policing type. Sungu Sungu groups to extract information or proof from a suspect, which often involves torture. This evidence will be used to bring a suspect to trial.

Masese and Mwenzwa note that the crime rate in the Kisii region decreased after the appearance of the group, and the Sungu Sungu transformed itself by taking up the role of providing protection to community members, especially those involved in illegal activities and they became a ready weapon for hire by politicians or business people. Despite its origins as a community security force with ties to the police, the Sungu Sungu has increasingly turned criminal and murderous over the years. Similarly, at the start, serious theft that Sungu Sungu fought against was characterized by cattle stealing, but Sungu Sungu activities have now spread to robberies or murders. However, the Kenyan court system and the police in Kenya are highly corrupt and maintained that in such a situation, it is felt that the Sungu Sungu are the only group or body that can bring justice to Kenyans for theft. The U4 Anti-Corruption Resource Centre, in Switzerland and offers anti-corruption material, references stated in 2007 that the Sungu Sungu is officially tolerated by the state.

\section{The Sungu Sungu in Kuria}

The Sungu Sungu was first adopted by the Kuria ethnic group on the Tanzania-Kenya border, and later spread to the neighbouring Gusii ethnic group in Kenya. The Regional Centre on Small Arms (RECSA), an African inter-governmental research organization on small arms and light weapons proliferation (RECSA 2011), states that the Sungu Sungu is active in conflicts among the Kuria clans as well as conflicts with the neighbouring Maasai and Kipsigis of Trans Mara.Sources report that clans formed the Sungu Sungu to counter cattle raids on the Kuria by other groups (Heald 2009; RECSA 2011).

\subsection{Kuria Sungu Sungu Structure}

The Kuria Sungu Sungu groups developed community assemblies called iritongo to denounce thieves and to stop vengeance raids and avert war. The iritongo are democratic assemblies where all adult men have a right to speak, led by members of the 'ruling' generation (Heald 2009). The U4 Anti-Corruption Resource Centre states that the assembly represents all sections of the community to ensure impartiality. The assembly or iritongoconstitutes itself in a semicircle, with the older men taking up positions to the right and younger men to the left, where they are joined by women, who rarely play an active role (Heald 2009). Heald states that the iritongo may occur at any level, from that of a family cluster to that of the main political unit, the village, ward, or division in Tanzania, the sublocation or location in Kenya. They can be spontaneous gatherings, as for example, when suspected thieves have been apprehended and a crowd gathers to interrogate them, or they might be more formal meetings called by the elders or government officials to discuss issues of pressing concern, again, particularly the rising levels of raiding.

The Sungu Sungu is the policing arm of the iritongo. All Kuria assemblies have a policing arm, but some [Sungu Sungu] worked more closely with the local chiefs and some were dominated by inchaama, - a "conclave of ritual elders" that expels or curses thieves. The inchaama usually meet in secret and are responsible for the ritual wellbeing of the people, setting the dates of the initiation ceremonies, and ruling on other issues 
that affect the community. However, Heald explains that the inchaama rarely [play] an active role in the meetings of the iritongo. She said that many regard the inchaama as the 'real government' of the Kuria and describe them as the "high court" or 'court of final appeal".

After an inquisitional trial before the iritongo, punishments are given out (Heald 2009,). To extract evidence and to punish, Sungu Sungu performs "whippings, beatings, and legeza [which means] the unlocking (or breaking) of the ankles (Heald 2007). Legeza prevents a thief from ever running again and is said to be a traditional punishment for theft. Another punishment is shunning, which not only implies total ostracism, but denies access to all village services ... [and] ...many of those ostracized are effectively forced to migrate away Heald 2009. Banishment is another form of punishment which is used only for the most serious cases in Kuria, for the recalcitrant thief or one who has killed many people and the severity of the punishment meted out is deemed critical to the success of the Sungu Sungu and a measure of a 'strong' group. Corroborating information about the information in this section could not be found among the sources consulted by the Research Directorate within the time constraints of this Response.

\subsection{Membership in the Kuria Sungu Sungu}

Heald noted that among the Kuria, when Sungu Sungu groups first started, the whole community were members and participants most members of the community were forced to attend assemblies and officials were elected to the assembly and this ensured checks on actions of the officials, as many people were present. Further, all age groups and lineages were represented by the officials. This structure is mostly the same today, though the particulars vary from group to group.

Corroborating information could not be found among the sources consulted by the Research Directorate within the time constraints of this Response.

\subsection{Kuria District Government Actions Against the Sungu Sungu}

Heald noted that previously the Kenyan government had supported some of Sungu Sungu groups when they first startedfor example an MP in the Kuria District and the District Commissioner of Kuria supported it as it created peace in the district. However, she remarks that every commissioner in each district as they change feels differently towards the Sungu Sungu and there is no consistency or guarantee of support as they also worry about human rights violations committed by the Sungu Sungu.Heald noted that the Sungu Sungu or policing arm of the iritongo or assembly are illegal in Kenya but the assemblies themselves are not illegal. Corroborating information could not be found among the sources consulted by the Research Directorate within the time constraints of this Response.

\subsection{State Protection in Kuria District}

Heald noted that there are many police in Kuria, but that they are often terrified of the thieves and the police are often accused of cooperating with the thieves. The general population perceives the police as not honest and untrustworthy, so they hesitate in seeking protection from them. Heald expressed the opinion that even with the 2010 constitutional changes for increased accountability within the police and the courts, the police and courts are corrupt and useless in providing justice.

\section{The Sungu Sungu in Kisii}

The Sungu Sungu began operating in that district in 2002 as a vigilante group. Human Rights Watch observed insecurity due to a 10-year-old gang called Sungu Sungu, which began as a community vigilante group and has been associated with criminal activity and killings in the Kisii region.Masese and Mwenzwa note that the founding goal of the Kisii Sungu Sungu was "eliminating crime and to some extent it succeeded in this endeavour as many criminals were either killed by the group members or forced to flee from "Gusiiland" (Human Rights Watch 2013).

\subsection{Structure of the Kisii Sungu Sungu}

Masese and Mwenzwa indicate that, unlike the Kuria, who took the initiative to mobilize groups themselves, the provincial administration in Kisii took a leading role in forming Sungu Sungu groups. The provincial administration used its structure in the local level (village) to mobilize local leadership to come up with a group of volunteers (Sungusungu) who would assist them in identifying and arresting criminals. There are two types of Kisii Sungu Sungu groups:

The community policing type supplements the work of security agencies of the state as they fight against crime. They identify criminals, arrest them, and hold them accountable. They are an informal system of justice. Their organizational structure composes of a chairman, secretary, religious leaders, teachers, civil servants from the government, youth members, and policemen. Their structure begins from the village managed by local community elders, to the location led by a chief, to the division led by a district officer, to the district 
led by a district commissioner.The social policing type believes they are custodians of customs and traditions of a community. Their organizational structure also comprises of a chairman, secretary, commanders who arrest people and administer justice, and youths serving the role of soldiers. This is an informal system of justice that is led and ruled by traditions. Its structure is very difficult to identify as it can fluctuate because the number of youths serving in the role of soldiers can vary and is unclear (Masese, 2013).

While there are community policing or social policing types of Kisii Sungu Sungu groups, there is no clear distinction about which group is which type at a given time as they often change which,function they are performing depending on its activities, needs, or the political climate. They can change types when the government wants to arrest a suspected criminal but does not have evidence to formally prosecute that individual. The government will use Sungu Sungu as an informal way to arrest criminals or extract information via torture, which the government is not allowed to do. The government will often use Sungu Sungu to perform a community policing function when this is the case.

Each village administration includes the village elder, his council, the eturetimembers of the eturetiinformal court, a Sungu Sungu Chairman, and secretary (Masese and Mwenzwa, 2012). The Sungu Sungu Chairman presides over meetings; act as a link between other village elders and council members, and is in charge of all members of the Sungusungu and the contact person for those who required help from Sungusungu.The Sungu Sungu "soldiers" are below the leadership level and are all male volunteers under the control of a commander. Upon orders from the village elder and the council, the "soldiers" will apprehend criminals, spy, and gather evidence for criminal cases and disputes. Corroborating information for information provided in this section could not be found among the sources consulted by the Research Directorate within the time constraints of this Response.

\subsection{Membership of the Kisii Sungu Sungu}

Sungu Sungu members are volunteers and youth who are unemployed and less educated.Members undergo no training or induction on how to work amicably with the public. Open Democracy similarly reports that the group appeals to unemployed young men (2009). Masese notes that members are attracted to Sungu Sungu when they come from a poor, low educated, poor infrastructure community or area. Youth from this segment of society are particularly attracted to Sungu Sungu as it offers them money and a higher socioeconomic status. The Sungu Sungu targets weak people in society who have no access to the justice system, which are normally women and poor youth. There is also a sociological aspect to young men joining Sungu Sungu as it will prove their masculinity and in turn increase their social status in the Kisii.

Masese (2013) noted that some women are members of the community policing type of Sungu Sungu; however they do not occupy leadership positions and are not members of the social policing type. He further noted that statistics on membership are unclear and change, depending on the group. Corroborating information could not be found among the sources consulted by the Research Directorate within the time constraints of this Response.

\subsection{Activities in Kisii}

The Sungu Sungu organization began arbitrating on cases involving debtors, land disputes, family conflicts and adultery, punishing witches, and containing or fixing political and business competitors. When arresting suspects, the "soldiers" were allowed to assault or torture the suspect provided it did not lead to death. Among Kisii Sungu Sungu members, manhandling of suspects, assault, violence and extortion is not uncommon. Kisii Sungu Sungu also writes warning letters and when warnings are not heeded, people are secretly killed and all their properties destroyed. The victims' families are not allowed to bury their family member, mourn, or hold a funeral for their dead, and, if defied, they are "either killed or fined heavily.

The Sungu Sungu in Kisii are "violent and punish not only theft but also witchcraft. Masese and Mwenzwa (2013) state that Sungu Sungu members have engaged in eliminating witchcraft practices by "lynching suspected witches," which is the common preferred method of dealing with witches because the Kenya penal code has no provision in terms of penalties against witchcraft. Witchcraft is associated with women, as they are easy targets as witches because they have a low social status. Women are blamed for witchcraft and are likely to be killed if they are suspected.This is allowed due to their ambiguous identity. If a man is suspected of witchcraft, his house will be burnt down but he will not be killed, as it is assumed a woman influenced him into witcheraft and it is not his fault.

The Daily Nation $\left(7^{\text {th }}\right.$ February 2012), reported that Sungu Sungu were responsible for macabre killings of presumed witches and criminals in the Kisii district., the Standard reported (on 26 April 2011) that the Sungu Sungu was responsible for several killings in Kisii in 2011 and stated that, "despite being outlawed the Sungu Sungu already developed a life of its own and operates with impunity."The Daily Nation further reported on 22 September 2010, that the killing of four people suspected by the Kisii Sungu Sungu to be criminals, and whose heads were found "in a neat row;" the hands of the victims tied behind their backs indicating that the assailants 
might be Sungusungu. Corroborating information for the above-mentioned incidents could not however be found among the sources consulted within the time constraints.

\subsection{Kisii District Government Actions Against the Sungu Sungu}

The Standard reported in a 10 August 2011 article, that the Chairman of the Kisii South District Community Police stated they had 15 community policing members and hold monthly meetings with the Commanding Officer of each division. Furthermore, community policing members help police with intelligence in fighting crime and are vetted and are elected by the people (The Standard 10 Aug. 2011). The Chairman stated his community policing members have nothing to do with Sungu Sungu, which they consider as a "criminal outfit," adding that community policing members "cannot work with criminals". The Daily Nation reported later in a 23 September 2010 article, that the Kisii police boss denied the existence of Sungusungu in the area, saying the outfit was disbanded and many people are confusing Sungusungu with governmentsupported community policing groups.

\subsection{State Protection in Kisii District}

\subsubsection{Community Police and the Sungu Sungu in Kisii}

The Kenya Human Rights Commission (KHRC, 2011), the Kenya National Commission on Human Rights (KNCHR, 2011), and the National Cohesion and Integration Commission (NCIC, 2011) jointly expressed concern over crime and insecurity in Gusiiland after conducting a fact-finding mission on crime in the region (KHRC, 2011; The Star 19 Oct. 2011). They stated thatthough some members of the public and government officials report that Sungusungu is no longer in existence and that those who used to be members of Sungusungu are now members of community policing, thier findings indicated that the groups' criminal activities are still prevalent in various parts of Gusiiland (KHRC, 2011)

The KHRC reports human rights violations by Sungu Sungu under the guise of community policing in the Kisii district and that there seem to be no clear distinction between Sungusungu activities and governmentsponsored community policing. They report that Sungu Sungu activities in Gusiland include:Overstepping community policing mandate, for example arresting and detaining suspects in illegal holding cells and passing judgments in "Kangaroo" courts; murders of suspected "criminals", and in some instances, denial of burial rights in their homes; assault and causing grievous bodily harm to purported members of Community Policing;Issuance of threats to deter people from reporting criminal activities of purported members of Community Policing; issuance of threats by politicians, public officials as well as civilians to use the Sungu sungu to threaten or assault others;Enforced disappearance; and extortion of funds from members of the public allegedly for payment of security services. Other critical crimes committed by the group include exchanging sex in lieu of payment for protection; and enforcing a parallel justice system, where due course of law is interfered with and "punishment" is meted out extra-judiciously. Further information about state protection for victims of the Sungu Sungu in Kisii is not easy to be found.

\subsection{State protection for the sungu sungu}

\section{State Efforts and Effectiveness of State Protection}

The pervasive corruption of state officialdom in Kenya became ever more corrosive and that such corruption is embedded in every institution of the state. According to Freedom House (2013), the police and the judiciary are among the most corrupt institutions in Kenya. Responding to the inadequacies in crime prevention by the Kenyan government, the Government of Kenya has embraced community policing to supplement the work of official security agents (Masese and Mwenzwa 2009). This approach aimed to establish active partnerships between different stakeholders the fight crime.

In 2009, Heald stated that the Sungu Sungu resulted from the Kenyan government's difficulty in maintaining any semblance of law and order in the rural hinterland. Further, the Kenyan administration has allowed sungusungu groups to codify their own laws and set out their own punishments. In effect, the national penal code has been suspended (Heald 2009). As a result, the Kenyan government stands uneasy here, encouraging such codification, endorsing community action, and offering protection to sungusungu groups.

The Institute for Security Studies (ISS, 2007), an African organization that aims to enhance security in Africa, noted that during an inquiry into Kenyan security focusing on criminal gangs such as the Sungu Sungu, the police were accused of colluding with criminals. The ISS (2007) reports that the Kenyan police have been accused of being unable to fight spiralling crime especially relating to the crackdown on organized criminal groups, such as Sungu Sungu.The government does not give protection to victims, as often, the government is the one ordering or is aware of Sungu Sungu activities. Both mutually benefit from each other's activities and are usually always aware of what the other is doing. The government in particular benefits as it gets around the formal justice system. 


\subsection{Sungu Sungu and Political activities}

In 2013, the Kenyan government's National Crime Research Centre released a report by the Kenyan Attorney General that accuses police of "colluding with some members of these illegal groups including Sungu Sungu (The Standard 4 Sept. 2013; The People 31 Aug. 2013), while some allegedly ignore useful information from the public that may help them stop their illegal activities. The Kenyan newspapers stated that this report concluded thatsome politicians give money to these gangs for political supportand some members of these gangs occupy elected public positions. According to Masese (2013) during elections, the relationship between the government and Sungu Sungu changes. The Sungu Sungu become a political group for hire and are used to protect] a particular political group, as they are seen as a security enforcer for political rallies. They will not kill opponents; they will only threaten them and make their campaigns difficult to conduct. Sungu Sungu leaders at this time will have a direct link to politicians during campaigns.

\subsection{Case Study}

\subsubsection{Case Study 1}

"Jane" is a woman aged 36 years who lost her mother at a tender age of thirteen just before joining secondary school. That marked the end of her education and stability of shelter. She thus joined others in the streets after failed attempts to work as a househelp in the city. In the street, she was not lucky either because after four months she became pregnant thus adding another burden on her shoulder. In the street she participated in being hired to traffic drugs from one corner of the street to the other, she could be given out to men for a night by seniors in the street and money paid to them. She is a senior and doing the same to other younger girls who come to the streets. Besides, she is now living children between 5-8 years to be used in begging along the streets. Older children between 9-15 years force adults in the streets using human waste (faeces) to coerce them into giving money because if they go back in the evening empty handed, they will not have a roof over their heads or food for the day.

\subsubsection{Case Study 2}

"George" (27 years) joined other youth networks after being forced to street life by hostile life at home by the step mother at the age of ten. In the streets he did quite a number of errands such as being used by mechanics to vandalize parked vehicles removing mirrors, head lamps etc. He says he has since graduated to manning public transport routes at a fee, assistingresidents in the informal settlements to connect illegal water and electricity supply, providing security and assisting in getting houses for tenants. Some members of the group are hired to collect garbage and protect dumping sites for businessmen and women who use such places to collect recyclable materials for their business. Other members who have since gone back to the village have been hired to provide security. He says some have gone a notch higher by charging villagers a percentage of their produce such as milk, potatoes, maize sold including bride price paid.

\subsection{Conclusion}

Youth special movements and social network in Kenya is quickly gaining around especially with increasing numbers of the unemployed youth. From interviews, the movements enlarged the introduction of Structural Adjustment Programmes(SAPs) which saw many parents leave employment as a result of retrenchment, others sent home after being given "golden handshake" - a package for early retirement which was not invested well. Besides parents leaving mainstream employment, SAPs brought with it cost sharing in education, health among other institutions thus making life difficult for many youth dropping out of school due to lack of support from their parents. They had no choice but to form special movements and social networks for survival which in most cases has become a nuisance to the society despite the society using them for their own social, economic and political gains.

\subsection{Recommendation}

Youth special movements and social network in Kenya has gained ground and deeply rooted in the society. In order to make the movements useful to society, the society starting with the family should socialize youth a new. The state should empower youth with skills which can help them engage in meaningful activities which can improve their livelihoods positively. The state should take over activities such as providing security and social protection to the youth.

\section{References}

[1]. $\quad$ Al Shahid Network. (2010) Wilfred Mulliro. "Kenya Declares Somalia's Al Shabab Among Organised ～Illegal Gangs." http://english.alshahid.net/archives/14255 [Accessed 20 Apr. 2014]

[2]. Judie Kaberia (2008) "Parliament to Investigate Activities of Illegal Groups." http://www.capitalfm.co.ke/news/2008/07/parliamentto-investigate-activities-of-illegal- groups/

[3]. Committee to Protect Journalists (CPJ), (2012) Tom Rhodes. "Attacks on the Press in 2011." http://www.cpi.org/2012/02/attackson-the-press-in-2011-a-killing-and-a-cover.php 
[4]. The Daily Nation. 7 February (2012) "Call to Lock Out Kenyan Police from Business." http://allafrica.com/stories/201202080597.html

[5]. $\quad$. 23 September (2010) "Police Step Up Search for Residents' Killers."

[6]. $\quad 22$ September (2010) Jacob Owiti. "Terror Grips Village as Vigilante Gang Strikes, Killing $\quad$ Four People."

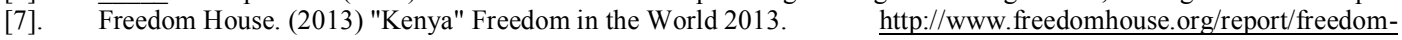
world $/ 2013 /$ kenya

[8]. Heald, Suzette, (2013) Crisis States Research Centre at the London School of Economics. 22 October 2013.

[9]. $\quad 21$ October 2013. Correspondence with the Research Directorate

[10]. 18 October 2013. Correspondence with the Research Directorate

[11]. 2009. "Reforming Community, Reclaiming the State: The Development of Sungusungu in Northern Tanzania." Community Policing: International Patterns and Comparative Perspectives. http://www.youblisher.com/p/255662-Community-Policing$\underline{\text { International- Patterns/ }}$

[12]. March 2007. Making Law in Rural East Africa: Sungusungu in Kenya. Crisis States Research Centre Working Papers, the London School of Economics.

[13]. Human Rights Watch. 8 February (2013) High Stakes: Political Violence and the 2013 Elections in Kenya. http://www.refworld.org/country,,HRW,,KEN,,511508df2,0.html

[14]. Institute for Security Studies (ISS). 19 July (2009) "To What Extent Is the Government of Kenya Committed to Police Reforms?" http://www.issafrica.org/iss-today/to-what-extent-is-the- government-of-kenya-committed-to-police-reforms

[15]. $\quad \begin{aligned} & \text { 2007. Augusta Muchai. "Police on Trial at Kenyan Public Hearings on Security." } \\ & \text { [16]. Human Rights Commission (KHRC). } 23 \text { October (2011) "Sungusungu: Merchants }\end{aligned}$

[16]. Kenya Human Rights Commission (KHRC). 23 October (2011) "Sungusungu: Merchants of Terror and Death in Kisii." http://www.khrc.or.ke/media-centre/press-releases/101-sungusungu- merchants-of-terror-and-death-in-kisii.html

[17]. Kisii.com. 23 January 2008. "Police Investigate Presence of Outlawed 'Sungusungu' and 'Chinkororo' Vigilante Groups." http://www.kisii.com/2007-elections/275-police-investigate-presence-of-outlawed-sungusungu-and-chinkororo-vigilantegroups?tmpl=component\&print $=1$ \&page $=$

[18]. Masese, E. R., and E. Mwenzwa. (2012) "The Genesis and Evolution of Sungusungu Vigilante Group Among the Abagusii Ethnic Group of Kenya." $\quad$ Journal of $\quad$ Elixir 42 Social 4 Sciences. http://www.elixirpublishers.com/articles/1350725941 42\%20(2012)\%206485-6492.pdf [19]. Open Democracy. 2 September (2009) "Militias, Gangs and Vigilantes in Kenya: the $\begin{gathered}\text { Consequences of Abandoning the } \\ \text { Reform Agenda." http://www.opendemocracy.net/article/email/militias-gangs-and-vigilantes-in-kenya-the- }\end{gathered}$ consequences-ofabandoning-the-reform-agenda

[20]. The People. 31 August (2013) "Organised Gangs on Steady Rise, Crime Report Indicates."

[21]. Regional Centre on Small Arms (RECSA). (2011) Manasseh Wepundi. An Analysis of Disarmament Experiences in Kenya. http://www.recsasec.org/publications/Kenya\%20Report.pdf

[22]. The Standard. 4 September (2013). "Ransom Gangs Hit Nairobi, Says National Crime Research Centre Report."

[23]. _ _ 10 August 2011. "Dark Secrets of Kenya's Deadliest Gang."

[24]. 26 April 2011. "Kisii Leaders Must Bottle Sungu Sungu Genie."

[25]. 22 November 2010. Robert Nyasoto. "Sungu Sungu Vigilantes Group Unleashes Terror Against Its Targets with Ruthlessness and Impunity."

[26]. $\quad 20$ October 2010. Cyrus Ombati. "State Outlaws 33 Criminal Gangs."

[27]. The Star.1 September 2013. Dominic Wabala. "Kenya Has 46 Criminal Gangs, Report Reveals."

[28]. $\quad 19$ October 2011. Amos Nyambane. "Commissions Say Sungu Sungu a 'National Disaster'."

[29]. 21 October 2010. Maxwell Masava. "Gangs Outlawed."

[30]. 23 September 2010. Angewnyi Gichana. "Two Beheaded Men Had Been Linked to Cleric's Murder." http://www.thestar.co.ke/news/article-83295/two-beheaded-men-had-been-linked-clerics-murder

[31]. U4 Anti-Corruption Resource Centre (U4). 23 February 2012. Marie Chêne. "Community Policing as a Tool Against Corruption." Chr. Michelsen Institute.

[32]. United Nations (UN). 22 February 2008. Integrated Regional Information Networks (IRIN). "Kenya: Armed and Dangerous." http://www.irinnews.org/report/76896/kenya-armed-and- dangerous

[33]. United States (US). 19 April (2013). Department of State. "Kenya" Country Reports on Human Rights Practices for 2012. http:/www.state.gov/j/drl/rls/hrrpt/2012/af/204131.htm 